高分子論文集 (Kobunshi Ronbunshu), Vol. 32, No. 3, pp. 189-195 (Mar., 1975)

\title{
メタクリル酸 2-アセトキシェチルのラジカル重合
}

\author{
野間 夹之*1 $・$ 丹羽 政三*1 ・飯田 真司*1 $・$ 中里 豊*1
}

(受付 1974 年 9 月 27 日・審査終了 1974 年 12 月 23 日)

\begin{abstract}
要 旨 メタクリル酸 2-アセトキシェチル(I) のホモポリマー扰よびコポリマーの水酸化カリウム による加水分解をジオキサン一水 (3:1 容積比) 中 30 および $50^{\circ} \mathrm{C}$ で行った。 このような反応条 件ではアセチル基は非常に速く, かつ完全に加水分解されたが, メタクリル酸エステル基の加水分解 は無視できることが分かった。それゆえこの反応をコポリマー中のI 基の定量に用いた．Ｉとスチレ ン(II), メタクリル酸メチルまたはメタクリル酸 2-ヒドロキシェチル(III) とのラジカル共重合をア セトンまたは $N, N$-ジメチルホルムアミド(IV) 中 $50^{\circ} \mathrm{C}$ で行った。モノマー反応性比 (MRR) はそ れぞれ $0.57\left(r_{\mathrm{A}}\right)$ および $0.44\left(r_{\mathrm{B}}\right), 1.07\left(r_{\mathrm{\Delta}}\right)$ および $0.93\left(r_{\mathrm{m}}\right), 1.00\left(r_{\mathrm{A}}\right)$ おおよび $1.00\left(r_{\mathrm{B}}\right)$ であ った. III とII との IV 中 $50^{\circ} \mathrm{C}$ でのラジカル共重合における MRR は $0.53\left(r_{\mathrm{B}}\right)$ および $0.45\left(r_{\mathrm{s}}\right)$ であった。
\end{abstract}

\section{1 緒 言}

メタクリル酸 2-ヒドロキシェチル (HEMA と略記す る）のポリマーおよびュポリマーは，ポリマーの変性や 医療面への応用などで注目されており，種々の報告 ${ }^{1) ~ b) ~}$ がみられるが，共重合に 関する研究(日),7) は比較的少な W.

HEMA の共重合の研究を行うため, 無水酶酸・ピリ ジン法によるコポリマーの水酸基定量を行ったところ, 測定値の再現性に疑問が生じた，その原因としてアセチ ル化物の加水分解されやすいことが考兄られたので， HEMA よりメタクリル酸 2-アセトキシェチル (AEMA と略記する）を合成し，そのホモポリマーおよびュポリ マーのアルカリ加水分解について実験するとともに，そ のラジカル共重合についての実験を行ったのでこれらに ついて報告する.

\section{2 実験方法}

\section{1 AEMA の合成}

還流冷却器付の $1 l$ 丸底フラスコに HEMA $130 \mathrm{~g}$, 無 水酢酸 $320 \mathrm{~g}$ 扣よびピリジン $320 \mathrm{~g}$ を加え, 少量の重 合禁止剂 (塩化第二銅) の存在下 $98^{\circ} \mathrm{C}$ で 5 時間反応さ せた，窒素気流中で減圧蒸留した粗 AEMA を洗液が中 性になるまで飽和塩化ナトリウム水溶液で洗浄を繰り返 し, 無水硫酸ナトリウム上で乾燥後, 窒素気流中で減圧 蒸留して沸点 $58.0 \pm 1^{\circ} \mathrm{C} / 0.5 \mathrm{mmHg}$ の留分を集めた。 重合直前に再蒸留した。

*1 同志社大学工学部 (亚602 京都市上京区烏丸今出川 東入ル)

\section{2 重合および共重合}

HEMA, スチレン (St と略記する) およびメタクリル 酸メチル (MMA と略記する) は市販品を常法で精製し て使用した. 重合開始剤の $\alpha, \alpha^{\prime}$-フゾビスイソブチロニ トリル (AIBN と略記する) は市販特級品をそのまま使 用し, 重合溶媒のアセトン拈よび $N, N$-ジメチルホルム アミド (DMF と略記する), 沈殿剤の石油ベンジンは常 法により精製して使用した。

モノマーおよび AIBN をアセトンあるいは DMF に 溶解して所定濃度の溶液を調製し, 常法で洗浄した重合 管に入れ，十分に窒素置換して溶封し， $50^{\circ} \mathrm{C}$ の定温槽 中で重合させた。所定時間後に重合管を深冷して重合 を停止し，開封して内容物を石油ベンジンまたは冷水 (HEMA を含む場合) 中に注いでポリマーを沈殿させ た、ポリマーはアセトンを溶剤, 石油ベンジンまたは冷 水・石油ベンジンを沈殿郕として再沈殿を繰り返して精 製した。

2.3 HEMA のホモポリマーおよびコポリマーのア セチル化

ポリマーを適当量のピリジンに溶解させ無水酢酸を加 えて $98^{\circ} \mathrm{C} て ゙ ~ 1$ 時間反応させた。室温まで泠却してか ら，反応物を多量の冷水中に注いでポリマーを沈殿させ た。ポリマーはジオキサンと石油ベンジンで再沈殿を繰 り返した。 その後再び同様の方法でア七チル化と再沈殿 とを繰り返した。

\section{4 アルカリ加水分解}

再沈殿精製したポリマーを常温で減压にして溶媒の大 部分を留去したのち, 直ちにジオキサンに溶解して所定 濃度の溶液とした。溶液の一定量を減圧下加温乾燥して 
正確な濃度を求めた。 ポリマー溶液 $30 \mathrm{~m} l$ と $0.1 \sim 0.3$ 規定の水酸化カリウム水溶液 $10 \mathrm{ml}$ とを反応温度にし てから混合して反応を行い，所定時間後に急冷して反応 を停止してから、フェノールフタレインを指示薬として 0.05 0.1 規定の塩酸で滴定した，同時に空試験を行っ て反応した水酸化カリウム量を求めた。

\section{3 実験結果と考察}

\section{1 AEMA の単独重合}

AIBNをもノマーに対して $0.5 \mathrm{wt} \%$ 使用し，モノマ 一初濃度 $2.0(\mathrm{~mol} / l)$ で, AEMA の単独重合をつセ卜 ン容液中 50 拈よび $70^{\circ} \mathrm{C}$ で行った。 その重合時間と重 合率の関係を Table 1 に示した. 同一条件における DMF 中の HEMA の単独重合ではしばしばゲル化が 起こったのに対して, AEMA の重合ではモノマーの精 製に十分に注意すれば， 50 および $70^{\circ} \mathrm{C}$ での重合とも にほぼ $100 \%$ の重合率まで全く均一系で進行した。ポリ メタクリル酸 2-フセトキシェチル (PAEMA と略記す る）はアセトンやジオキサンなどの有機溶媒に可溶性で あった. PAEMA のアセトン溶液の $30^{\circ} \mathrm{C}$ に拈ける粘
度測定から固有粘度数 $(\mathrm{d} l / \mathrm{g})[\eta]$ を求め, Table 1 に記 載した. [ク] は重合率の增加とともにやや減少する.

\section{2 木モポリマーの加水分解}

PAEMA およびDMF 溶夜重合で得たポリメタクリ ル酸 2-ヒドロキシェチル (PHEMA と略記する) の完 全アセチル化物のジオキサン・水 $\left(3: 1\right.$ 容積比)中 $50^{\circ} \mathrm{C}$ でのアルカリ加水分解の結果を Table 2 に示した.

AEMA 基初濃度はほほ $14.0(\mathrm{mmol} / \mathrm{l})$ および水酸化 カリウム初濃度は $25.0(\mathrm{mmol} / \mathrm{l})$ である.

PAEMA および PHEMA のアセチル化物のアルカ リ加水分解は非常に速く, $50^{\circ} \mathrm{C}$ ではアルカリ消費量が ほぼ 15 分で AEMA 基と当量に達し，その後反応時 間を長くしても (140 分後でも)，そのまま一定でアルカ リ消費量の增加は認められない，AEMA 基にはメタク リル酸エステルと酢酸エステルの二つのエステル基があ るが，一般にポリマー中のメタクリル酸エステル基の加 水分解は困難である。 PHEMA のアルカリ加水分解を 全く同一反応条件で行い, その結果も Table 2 に示した が，PHEMA はほとんど加水分解を受けず，24 時間後 においても反応率は $0.4 \%$ にすぎなかった。 したがっ

Table 1. Radical homopolymerization of 2-acetoxyethyl methacrylate in acetone at 50 and $70^{\circ} \mathrm{C}$.

\begin{tabular}{ccccccc}
\hline \hline \multirow{3}{*}{$50^{\circ} \mathrm{C}$} & Time (hr) & 5.0 & 8.0 & 15.0 & 24.0 & 32.8 \\
\cline { 2 - 6 } & Conversion $(\%)$ & 38.97 & 55.92 & 71.88 & 91.09 & 94.89 \\
& {$[\eta](\mathrm{d} l / \mathrm{g})$} & 0.721 & 0.694 & 0.691 & 0.619 & 0.613 \\
\hline \multirow{3}{*}{$70^{\circ} \mathrm{C}$} & Time $(\mathrm{hr})$ & 2.0 & 4.0 & 6.0 & 8.0 & 9.5 \\
\cline { 2 - 7 } & Conversion $(\%)$ & 63.25 & 82.10 & 90.88 & 93.75 & 94.53 \\
& {$[\eta](\mathrm{d} l / \mathrm{g})$} & 0.281 & 0.251 & 0.227 & 0.233 & 0.223 \\
\hline
\end{tabular}

Table 2. Alkaline hydrolyses of poly-2-acetoxyethyl methacrylate (PAEMA), acetylated poly-2-hydroxyethyl methacrylate (Ac. PHEMA) and poly-2-hydroxyethyl methacrylate (PHEMA) with potassium hydroxide in dioxane-water $(3: 1 \mathrm{vol})$ at $50^{\circ} \mathrm{C}$.

\begin{tabular}{cccccccccccc}
\hline \hline \multirow{3}{*}{ PAEMA } & Time $(\mathrm{min})$ & 5 & 10 & 15 & 20 & 25 & 30 & 40 & 60 & 120 & 140 \\
\cline { 2 - 11 } & $\theta(\mathrm{mmol} / \mathrm{g})$ & 4.919 & 5.407 & 5.792 & 5.812 & 5.807 & 5.807 & 5.827 & 5.774 & 5.827 & 5.804 \\
& $A$ & 0.847 & 0.931 & 0.997 & 1.000 & 1.000 & 1.000 & 1.003 & 0.994 & 1.003 & 0.999 \\
\hline \multirow{4}{*}{ Ac. PHEMA } & Time $(\mathrm{min})$ & 5 & 10 & 15 & 20 & 25 & 30 & 40 & 60 & 120 & 140 \\
& $\theta(\mathrm{mmol} / \mathrm{g})$ & 3.642 & 5.490 & 5.897 & - & 5.839 & 5.815 & 5.839 & - & 5.816 & 5.814 \\
& $A$ & 0.627 & 0.945 & 1.005 & - & 1.006 & 1.001 & 1.006 & - & 1.002 & 1.001 \\
\hline \multirow{4}{*}{ PHEMA } & Time (min) & 30 & 45 & 60 & 75 & 90 & 105 & 120 & 150 & 180 & 1440 \\
\cline { 2 - 10 } & $\theta(\mathrm{mmol} / \mathrm{g})$ & 0.014 & -0.027 & 0.007 & 0.000 & -0.048 & 0.014 & 0.048 & 0.075 & 0.034 & 0.023 \\
& $A$ & 0.002 & -0.005 & 0.001 & 0.000 & -0.008 & 0.002 & 0.008 & 0.013 & 0.007 & 0.004 \\
\hline
\end{tabular}

$\theta$, consumed $\mathrm{KOH}(\mathrm{mmol}) /$ polymer $(\mathrm{g})$

$A$, consumed KOH (mol)/AEMA- or HEMA-unit (mol) in polymers. 


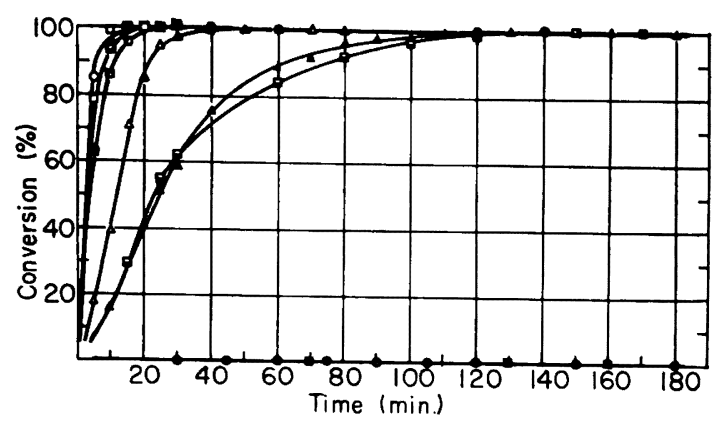

Fig. 1. Alkaline hydrolyses of poly-2-acetoxyethyl methacrylate $(O)$; acetylated poly-2-hydroxyethyl methacrylate $(\otimes)$; poly-2-hydroxyethyl methacrylate (O); polymethyl methacrylate (a) and copolymers of 2-acetoxyethyl methacrylate with methyl methacrylate; $f_{\mathbf{A}}=0.73$ $(\square) ; 0.50(\square) ; 0.30(\square) ; 0.10(\boxminus)$ and with styrene; $f_{\mathbf{\Delta}}=0.60(\triangle) ; 0.30(\mathbf{\Delta})$.

て,このような条件下における AEMA 基のアルカリ 加水分解では, アセチル基の反応が速やかに進行し，メ タクリル酸エステル基の加水分解は無視しらるから，ポ リマー中の AEMA 基の定量法として使用できる。 そ れとともに HEMA を含むコポリマーの組成分析に無水 酢酸・ピリシンン法による水酸基定量を用いる場合には, アルカリによる加水分解をきわめて受けやすいアセチル 基のために終点が不めいりょらになり, 再現性のよい結 果の得にくいことが考えられ，HEMA 基をアセチル化 した後にヶン化価を求める方が適当であろう。

\section{3 コポリマーの組成分析}

加水分解によるコポリマー中の AEMA 基の定量を行 うため, AEMA と St および AEMA と MMA の重 合率数％のコポリマーおよびポリメタクリル酸メチル
(PMMA と略記する) を作成して, 同様の条件下でのア ルカリ加水分解を行い，その結果を Fig. 1 に示した. PMMA はPHEMA と同様にこの条件下ではほとんど 加水分解されない，コポリマーでは，仕込みモノマー中 の AEMA のモル分率 $f_{\mathrm{A}}$ が減少するに従って反応速 度も低下するが，いずれのコポリマーも160 分以内で一 定値に達している。 また $f_{\Delta}$ が 0.30 の $\mathrm{St}$ とのコポリ マーでは反応溶媒への溶解性の関係で溶媒量を 2 倍にし ているが，この場合も 160 分以内で一定值に達してい る. したがって $f_{\mathrm{A}}$ の小の場合には反応時間と溶媒量に 留意すれば，非常に簡単で正確な組成分析ができる.

コポリマー中の AEMA 基のモル分率 $F_{\mathrm{A}}$ は (1) 式 で計算される，ただし $M_{\mathrm{x}}$ はュモノマー $(X)$ の分子量 であり, $(\mathrm{mmol} / \mathrm{g}) \theta$ はコポリマー $1 \mathrm{~g}$ 当たりのアルカ リ消費量である。

$$
F_{\mathrm{A}}=\frac{M_{\mathrm{x}} \times \theta}{10^{3}-\left(172-M_{\mathbf{x}}\right) \times \theta}
$$

\section{4 モノマー反応性比}

AIBN を全モノマーの $0.5 \mathrm{wt} \%$ 使用したアセトン中 $50^{\circ} \mathrm{C}$ での AEMA と St の共重合（全モノマー初濃度 $\left.[\mathrm{M}]_{0}=3.00 \mathrm{~mol} / l\right)$ および AEMA と MMA の共重合 $\left([\mathrm{M}]_{0}=4.00 \mathrm{~mol} / l\right)$, および DMF 中 $50^{\circ} \mathrm{C}$ での AEMA と HEMA の共重合 $\left([\mathrm{M}]_{0}=4.00 \mathrm{~mol} / l\right)$ における初期 コポリマー (重合率 $5.0 \mathrm{wt} \%$ 前後) の $F_{\mathrm{A}}$ と $f_{\mathrm{A}}$ との 関係を Table 3 にまとめて示した。 この結果から $f(F$ $-1) / F$ 対 $f^{2} / F$ および $(F-1) / f$ 対 $F / f^{2}$ のグラフを描 いたのが Fig. 2，3，および 4 であり，いずれの共重合 においても両者とも見事な直線関保があり，通常の 2 成 分共重合に対する (2) および (3) 式多，9)が成立する。 た だし， $r_{\mathrm{A}}$ および $r_{\mathrm{x}}$ は AEMA およびュモノマーの反 応性比であり, $f=f_{\mathrm{A}} /\left(1-f_{\mathrm{A}}\right)$ および $F=F_{\mathrm{A}} /\left(1-F_{\mathrm{A}}\right)$ で ある。

Table 3. Molar fractions of 2-acetoxyethyl methacrylate in copolymers $\left(F_{\mathbf{A}}\right)$ and in the monomers $\left(f_{\mathbf{A}}\right)$ for the copolymerizations of 2-acetoxyethyl methacrylate with styrene (St), methyl methacrylate (MMA) or 2-hydroxyethyl methacrylate (HEMA) at $50^{\circ} \mathrm{C}$.

\begin{tabular}{|c|c|c|c|c|c|c|c|c|c|c|c|c|}
\hline \multirow[b]{2}{*}{ St } & $f_{\mathbf{A}}$ & 0.200 & 0.300 & 0.400 & 0.500 & 0.600 & 0.700 & 0.800 & 0.850 & & \multirow[b]{2}{*}{$\begin{array}{c}r_{\mathrm{A}} \\
0.57\end{array}$} & \multirow[b]{2}{*}{$\begin{array}{l}r_{\mathrm{s}} \\
0.44\end{array}$} \\
\hline & $F_{\mathbf{A}}\left\{\begin{array}{l}\text { Found } \\
\text { Calcd }\end{array}\right.$ & $\begin{array}{l}0.289 \\
0.293\end{array}$ & $\begin{array}{l}0.374 \\
0.380\end{array}$ & $\begin{array}{l}0.466 \\
0.454\end{array}$ & $\begin{array}{l}0.529 \\
0.522\end{array}$ & $\begin{array}{l}0.600 \\
0.589\end{array}$ & $\begin{array}{l}0.655 \\
0.662\end{array}$ & $\begin{array}{l}0.750 \\
0.747\end{array}$ & $\begin{array}{l}0.797 \\
0.797\end{array}$ & & & \\
\hline \multirow{2}{*}{ MMA } & $f_{A}$ & 0.100 & 0.200 & 0.300 & 0.400 & 0.500 & 0.600 & 0.700 & 0.800 & 0.900 & \multirow{2}{*}{$\begin{array}{c}r_{\mathrm{A}} \\
1.07\end{array}$} & \multirow[b]{2}{*}{$\begin{array}{l}r_{\mathrm{m}} \\
0.93\end{array}$} \\
\hline & $F_{\Delta}\left\{\begin{array}{l}\text { Found } \\
\text { Calcd }\end{array}\right.$ & $\begin{array}{l}0.109 \\
0.107\end{array}$ & $\begin{array}{l}0.211 \\
0.212\end{array}$ & $\begin{array}{l}0.314 \\
0.315\end{array}$ & $\begin{array}{l}0.415 \\
0.417\end{array}$ & $\begin{array}{l}0.512 \\
0.517\end{array}$ & $\begin{array}{l}0.621 \\
0.617\end{array}$ & $\begin{array}{l}0.735 \\
0.714\end{array}$ & $\begin{array}{l}0.818 \\
0.811\end{array}$ & $\begin{array}{l}0.906 \\
0.906\end{array}$ & & \\
\hline \multirow[b]{2}{*}{ HEMA } & $f_{\Delta}$ & 0.100 & 0.200 & 0.300 & 0.400 & 0.500 & 0.600 & 0.700 & 0.800 & 0.900 & \multirow[b]{2}{*}{$\begin{array}{c}r_{\mathrm{A}} \\
1.00\end{array}$} & \multirow[b]{2}{*}{$\begin{array}{r}r_{\mathrm{H}} \\
1.00\end{array}$} \\
\hline & $F_{\Delta}\left\{\begin{array}{l}\text { Found } \\
\text { Calcd }\end{array}\right.$ & $\begin{array}{l}0.100 \\
0.100\end{array}$ & $\begin{array}{l}0.194 \\
0.200\end{array}$ & $\begin{array}{l}0.296 \\
0.300\end{array}$ & $\begin{array}{l}0.399 \\
0.400\end{array}$ & $\begin{array}{l}0.496 \\
0.500\end{array}$ & $\begin{array}{l}0.600 \\
0.600\end{array}$ & $\begin{array}{l}0.698 \\
0.700\end{array}$ & $\begin{array}{l}0.797 \\
0.800\end{array}$ & $\begin{array}{l}0.899 \\
0.900\end{array}$ & & \\
\hline
\end{tabular}




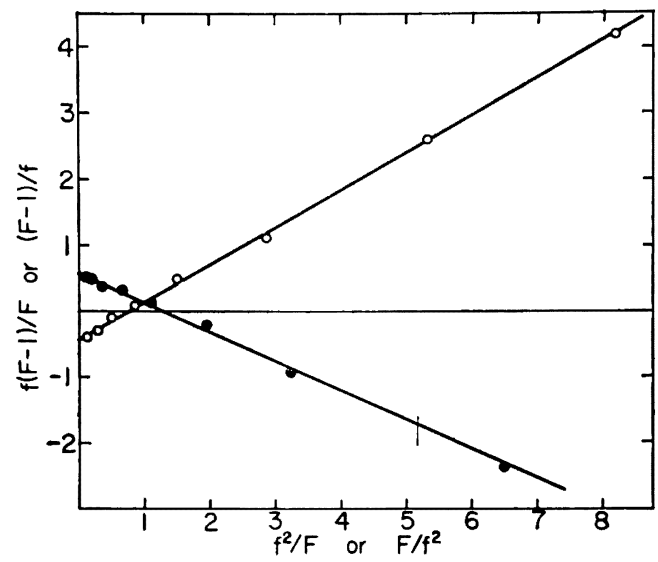

Fig. 2. $f(F-1) / F$ vs. $f^{2} / F(O)$ and $(F-1) / f$ vs. $F / f^{2}(\bullet)$ for the copolymerization of 2 acetoxyethyl methacrylate with styrene in acetone at $50^{\circ} \mathrm{C}$.

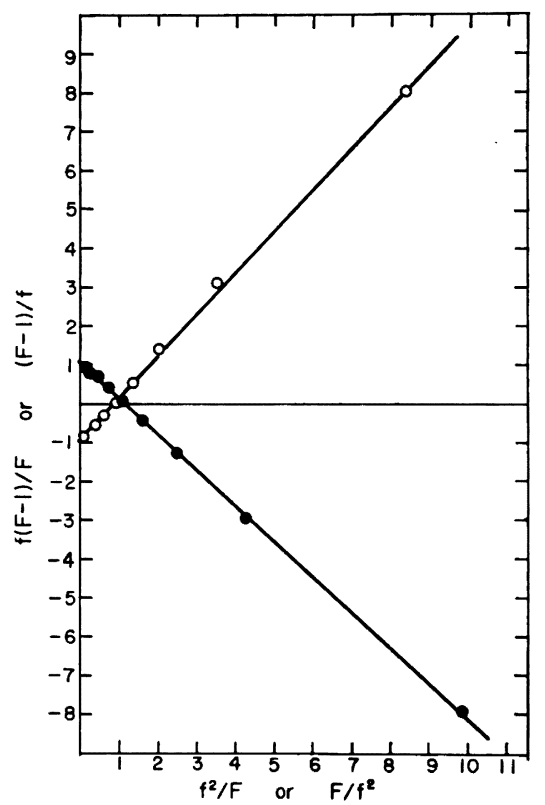

Fig. 3. $f(F-1) / F$ vs. $f^{2} / F(\bigcirc)$ and $(F-1) / f$ vs. $F / f^{2}(0)$ for the copolymerization of 2 acetoxyethyl methacrylate with methyl methacrylate in acetone at $50^{\circ} \mathrm{C}$.

$$
\begin{aligned}
& \frac{f(F-1)}{F}=r_{\Delta}\left(\frac{f^{2}}{F}\right)-r_{\mathrm{x}} \\
& \frac{(F-1)}{f}=r_{\mathrm{A}}-r_{\mathrm{x}}\left(\frac{F}{f^{2}}\right)
\end{aligned}
$$

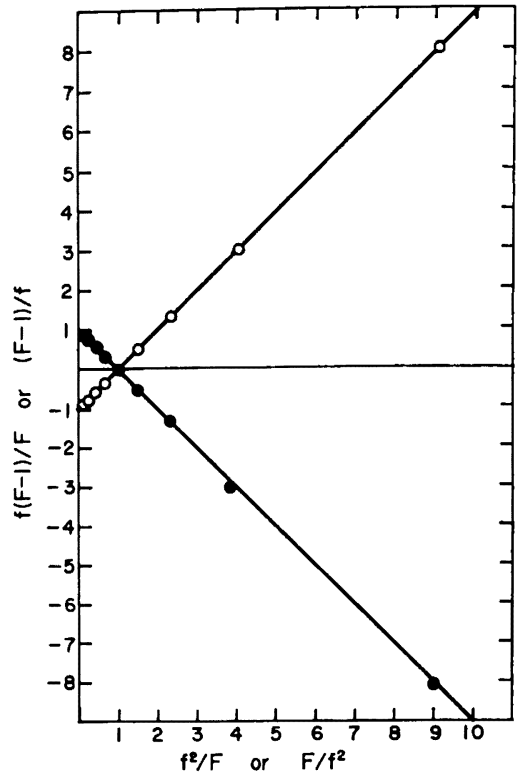

Fig. 4. $f(F-1) / F$ vs. $f^{2} / F(O)$ and $(F-1) / f$ vs. $F / f^{2}(\Theta)$ for the copolymerization of 2 acetoxyethyl methacrylate with 2-hydroxyethyl methacrylate in $N, N$-dimethyl formamide at $50^{\circ} \mathrm{C}$.

これらの直線の傾斜抢よび縦軸との切片から $r_{\mathbf{A}} お よ$ び $r_{\mathbf{x}}$ を求めて, これらの值も Table 3 に示した. こ の $r_{\mathrm{A}}$ および $r_{\mathrm{x}}$ を用いて (2) または (3) 式で求めた $F_{\Delta}$ の計算值も Table 3 に記載したが， $F_{\Delta}$ の計算値と 実測值は非常によく一致する.

通常の 2 成分共重合に扣けるモノマ一反応性比は周知 のよらに (4) および (5) 式成で示され，これを変形すれ

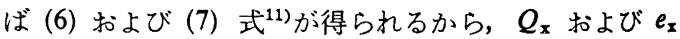
に文献值 ${ }^{12)}$ を採用して $\ln \left(r_{\mathrm{A}} \cdot Q_{\mathrm{x}}\right)$ 対 $e_{\mathrm{x}}$ および $\left[\ln \left(r_{\mathrm{x}}\right]\right.$ $\left.\left.Q_{\mathrm{x}}\right)+e_{\mathrm{x}}{ }^{2}\right]$ 対 $e_{\mathrm{x}}$ のプロットを行ったのが Fig. 5 であ る.

$$
\begin{aligned}
& r_{\mathrm{A}}=\left(\frac{Q_{\mathrm{A}}}{Q_{\mathrm{x}}}\right) \cdot \mathrm{e}^{-e_{\mathrm{A}}\left(e_{\mathrm{A}}-e_{\mathrm{x}}\right)} \\
& r_{\mathrm{x}}=\left(\frac{Q_{\mathrm{x}}}{Q_{\mathrm{A}}}\right) \cdot \mathrm{e}^{-e_{\mathbf{X}}\left(e_{\mathrm{X}}-e_{\mathrm{A}}\right)} \\
& \ln \left(r_{\mathrm{A}} \cdot Q_{\mathrm{x}}\right)=\left[\ln Q_{\mathrm{A}}-e_{\mathrm{A}}{ }^{2}\right]+e_{\mathrm{A}} \cdot e_{\mathrm{x}} \\
& {\left[\ln \left(\frac{r_{\mathrm{x}}}{Q_{\mathrm{x}}}\right)+e_{\mathrm{x}}{ }^{2}\right]=-\ln Q_{\mathrm{A}}+e_{\mathrm{A}} \cdot e_{\mathrm{x}}}
\end{aligned}
$$

(6) および (7) 式によれば縦軸の位置が $\left[2 \ln Q_{\Delta}-e_{\Delta}^{2}\right]$ だけ移動した 2 本の平行する直線であるから，この条件 を満す直線を引き, 直線の縦軸の切片から $Q_{\Delta}$, 傾斜か ら $e_{\Delta}$ を求めた。 その結果 $Q_{\Delta}=0.83$ 拈よび $e_{\Delta}=0.36$ 


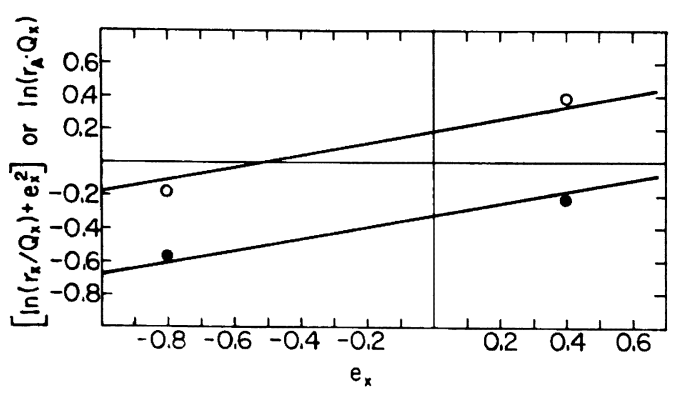

Fig. 5. $\left[\ln \frac{r_{x}}{Q_{x}}+e_{x}^{2}\right](\bigcirc)$ or $\ln \left(r_{\mathbf{A}} \cdot Q_{x}\right)(\bullet) v s . e_{x}$.

であった。

他方, AEMA と HEMA の $50^{\circ} \mathrm{C}$ でのラジカル共 重合におけるモノマー反応性比はともに 1.00 であった から，両者の $Q$ および $\boldsymbol{e}$ は等しいことになる。このこ とをさらに確認する目的で HEMA と St との共重合 を DMF 溶液中 $50^{\circ} \mathrm{C}$ で行った。仕込みモノマー中の HEMA のモル分率 $f_{\mathrm{H}}$ を種々に変化させて初期コポ リマーを収得し、これを完全にアセチル化したのち, AEMA のコポリマーの場合と同様にしてコポリマー中 の HEMA 基のモル分率 $F_{\mathrm{H}}$ を求め (式 (1) の $F_{\mathrm{A}}=F_{\mathrm{H}}$ ) その結果を Table 4 に示した。この結果から $f(F-1) /$ $F$ 対 $f^{2} / F$ 扰よび $(F-1) / f$ 対 $F / f^{2}$ のグラフを描くと Fig. 6 であり，両者ともに見事な直線関係があるから (2) および (3) 式が成立し, これらの直線の傾斜および 綎軸の切片から $r_{\mathrm{H}}=0.53$ および $r_{\mathrm{B}}=0.45$ が得られ た。 またこの $r_{\mathrm{B}}$ および $r_{\mathrm{B}}$ を用いて (2) または (3) 式 で求めた $F_{\text {B }}$ の計算值も実測值に上く一致した (Table 4 参照).

$r_{\mathrm{H}}$ および $r_{\mathrm{s}}$ から St の $Q$ および $e$ の文献值 ${ }^{12)}$ 用いて $Q_{\mathrm{B}}$ および $e_{\mathrm{B}}$ を計算すると， $Q_{\mathrm{B}}=0.85$ および $e_{\mathrm{B}}=0.40$ であった，さきに求めた $Q_{\mathrm{A}}=0.83$ および $e_{\Delta}=0.36$ であったから, 両者はほぼ同じである.

\section{5 AEMA・MMA コポリマーのアルカリ加水分}

\section{解速度}

種々の $F_{\mathrm{A}}$ の AEMA と MMA の初期コポリマーを 使用してジオキサン・水 $\left(3: 1\right.$ 容積比) 中 $30^{\circ} \mathrm{C}$ でフ ルカリ加水分解を行い, 反応水酸化カリウム量 $(\mathrm{mmol} / \mathrm{l})$

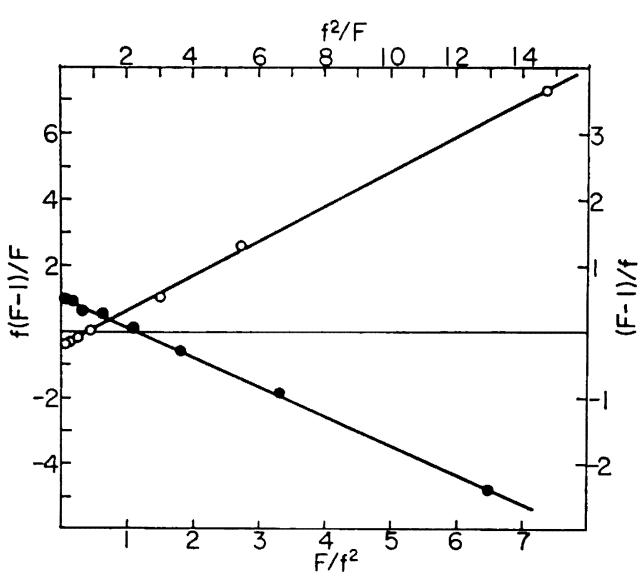

Fig. 6. $f(F-1) / F$ vs. $f^{2} / F(O)$ and $(F-1) / f$ vs. $F / f^{2}(0)$ for the copolymerization of 2 hydroxyethyl methacrylate with styrene in $N, N$-dimethylformamide at $50^{\circ} \mathrm{C}$.

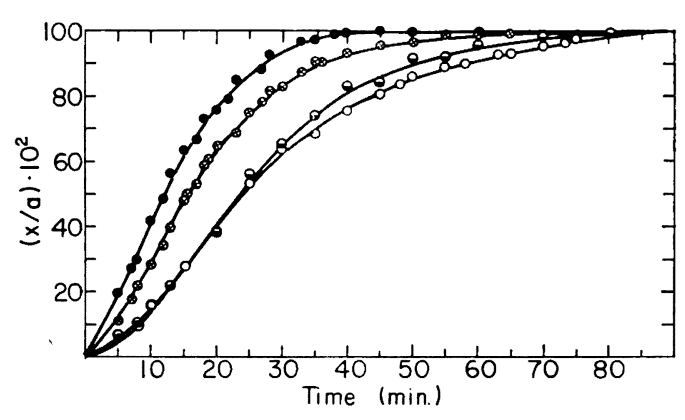

Fig. 7. Alkaline hydrolysis of the copolymers of 2-acethoxyethyl methacrylate (AEMA) and methyl methacrylate in dioxane-water (3: $1 \mathrm{vol})$ at $30^{\circ} \mathrm{C}$.

Initial concn. of acetyl group $=14.0(\mathrm{mmol} /$ $l)$ and $\mathrm{KOH}=25.0(\mathrm{mmol} / \mathrm{l})$. Molar fraction of AEMA-unit in copolymers $\left(F_{\mathbf{A}}\right)=0.316$ $(\bigcirc), 0.379(\Theta), 0.517(\otimes)$, and $0.740(\bullet)$.

Table 4. Molar fractions of 2-hydroxyethyl methacrylate in the copolymers $\left(F_{\mathrm{H}}\right)$ and in the monomers $\left(f_{\mathrm{H}}\right)$ for the copolymerization of 2-hydroxyethyl methacrylate with styrene in $N, N$-dimethyl formamide at $50^{\circ} \mathrm{C}$.

\begin{tabular}{lllllllllll}
\hline$f_{\mathrm{H}}$ & 0.200 & 0.300 & 0.400 & 0.500 & 0.600 & 0.700 & 0.800 & 0.900 & $r_{\mathrm{H}}$ & $r_{\mathrm{s}}$ \\
\cline { 1 - 8 }$F_{\mathrm{H}}\left\{\begin{array}{llllll}\text { Found } \\
\text { Calcd }\end{array}\right.$ & 0.288 & 0.380 & 0.446 & 0.519 & 0.589 & 0.644 & 0.746 & 0.846 & 0.53 & 0.45 \\
\hline
\end{tabular}




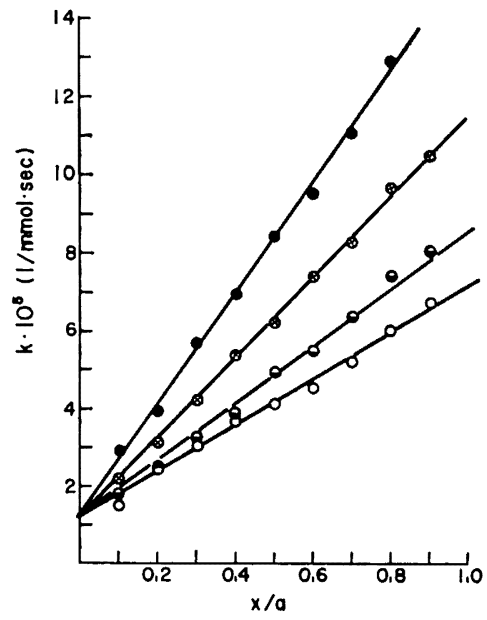

Fig. 8. Conversion $(x / a)$ vs. $k$

Molar fraction of 2-acetoxyethyl methacrylate unit in copolymers $\left(F_{\mathbf{A}}\right)=0.316(O), 0.379(\Theta)$, $0.517(\otimes)$, and $0.740(\bullet)$.

$x$ を求め, 反応水酸化カリウム量は反応ア七チル基量に 等しいと考えてアセチル基の反応度 $(x / a)$ を求めた。 た だし， $a$ はアセチル基の初濃度打よび $b$ は水酸化カリ ウム初濃度であり，ほぼ $14.0(\mathrm{mmol} / l)$ および 25.0 $(\mathrm{mmol} / \mathrm{l})$ であった。

$F_{\mathrm{A}}$ が $0.316,0.379,0.517$ および 0.740 のときの $x / a$ 対反応時間 $t$ のグラフを Fig. 7 に示した。この曲 線を因上微分して加水分解速度 $\mathrm{d} x / \mathrm{d} t$ を求め, 2 分子反 応としての速度定数 $(l / \mathrm{mmol} \cdot \mathrm{sec}) k=(\mathrm{d} x / \mathrm{d} t) /(a-x)(b$ -x) を計算した. Fig. 8 に $F_{\mathrm{A}}$ の異なる各コポリマー の $k$ と $x / a$ との関係を示した、いずれのコポリマーの 場合にも 2 分子反応速度式から求めた速度定数 $k$ は反応 度の增加とともにほぼ直線的に增大し, その増加の割合 は $F_{\mathrm{A}}$ の大なものほど大であった。したがって $F_{\mathrm{A}}$ のい

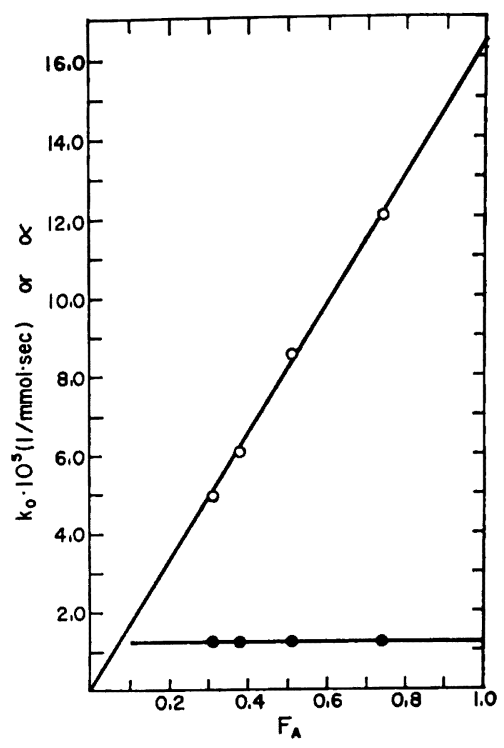

Fig. 9. Relationship between copolymer composition $\left(F_{\mathrm{A}}\right)$ and initial rate constant $\left(k_{0}\right)$ (๑) or $\alpha(O)$.

かんにかかわらず $k$ と $x / a$ との間にはほぼ (8) 式の関 係が認められた。

$$
k=k_{0}\left[1+\alpha\left(\frac{x}{a}\right)\right]
$$

ポリ酢酸ビニル (PVAc と略記する) のアルカリ加水分 解 ${ }^{19}$ などの高分子の化学反応には (8) 式と同様の関保が しばしば認められている。

各々を直線とみなして各直線の縦軸との切片およひ傾 斜から $k_{0}$ および $\alpha$ を求め (Table 5 参照)， $F_{\mathbf{A}}$ と $k_{0}$ または $\alpha$ との関係を Fig. 9 に示した. 初期反応速 度定数 $k_{0}$ は $F_{\mathrm{A}}$ に無関係に一定であるのに対して， $\alpha$

Table 5. Molar fractions of 2-acetoxyethyl methacrylate (AEMA) unit $\left(F_{\Delta}\right)$, mean length of AEMA unit $\left(\bar{l}_{\mathbf{A}}\right)$ and wt.(\%) of isolated AEMA unit $\left[W_{\mathbf{A}}(1)\right]$ in the copolymers, initial concn. of AEMA unit ([AEMA $\left.]_{0}\right)$ and potassium hydroxide $\left([\mathrm{KOH}]_{0}\right)$ and the values of $k_{0}$ and $\alpha$ in eq. (8) for the alkaline hydrolysis of the copolymer of AEMA and methyl methacrylate in dioxane-water $(3: 1 \mathrm{vol})$ at $30^{\circ} \mathrm{C}$.

\begin{tabular}{ccccccc}
\hline \hline$F_{\mathbf{\Delta}}$ & $\begin{array}{c}{[\mathrm{AEMA}]_{0}} \\
(\mathrm{mmol} / l)\end{array}$ & $\begin{array}{c}{[\mathrm{KOH}]_{0}} \\
(\mathrm{mmol} / l)\end{array}$ & $\begin{array}{c}k_{0} \\
(l / \mathrm{mmol} \cdot \mathrm{sec} .)\end{array}$ & $\alpha$ & $\begin{array}{c}W_{\mathbf{\Delta}}(1) \\
(\%)\end{array}$ & $\bar{l}_{\mathbf{\Delta}}$ \\
\hline 0.316 & 14.02 & 25.00 & $1.20 \times 10^{-5}$ & 4.96 & 46.79 & 1.46 \\
0.379 & 14.05 & 25.00 & $1.20 \times 10^{-5}$ & 6.08 & 38.56 & 1.61 \\
0.517 & 13.91 & 25.00 & $1.20 \times 10^{-5}$ & 8.58 & 23.33 & 2.28 \\
0.740 & 14.32 & 25.00 & $1.20 \times 10^{-5}$ & 12.00 & 6.76 & 3.85 \\
\hline
\end{tabular}


と $F_{\mathbf{\Delta}}$ との間には注ほ原点を通る直線関係が認められた。 参考までにこれらの直線関係を用いて $F_{\Delta}=1.0$ まで外 挿して PAEMA の $k_{0}$ と $\alpha$ を求めたところ， $k_{0}=1.20$ $\times 10^{-5}(\mathrm{l} / \mathrm{mmol} \cdot \mathrm{sec})$ 打よび $\alpha=16.4$ となる. 例えば， 坂口ら ${ }^{14)}$ によって求められたアセトン・水中 $30^{\circ} \mathrm{C}$ に打 ける PVAc 打よびポリ酶酸メタアリル (PMAAc と 略記する)の $k_{0}$ は $0.667 \times 10^{-5}(l / \mathrm{mmol} \cdot \mathrm{sec})$ 扰よび $1.67 \times 10^{-5}(l / \mathrm{mmol} \cdot \mathrm{sec})$ であるから, PAEMA の $k_{0}$ は 同じ第 1 級アルニールの酷酸エステルである PMAAc の $k_{0}$ と同程度であり, PVAc の $k_{0}$ の 1.8 倍大であ ることになる.

$\alpha$ は加水分解された基の隣接基への加速効果の結果と 考えられることもあるから AEMA 基の重量\% $W_{\mathbf{A}}(1)$ および AEMA 基の平均鎖 長 $\bar{l}_{\Delta}$ を(9) および (10) 式淿によって算出し Table 5 に記載した。

$$
\begin{aligned}
& W_{\mathbf{A}}(1)=\left[\frac{\left(1-f_{\mathbf{\Delta}}\right) \cdot 10}{1+\left(r_{\mathbf{\Delta}}-1\right) f_{\mathbf{A}}}\right]^{2} \\
& \bar{l}_{\mathbf{\Delta}}=\frac{1+\left(r_{\mathbf{\Delta}}-1\right) f_{\mathbf{\Delta}}}{1-f_{\mathbf{A}}}
\end{aligned}
$$

$W_{\mathbf{\Delta}}(1)$ が小なほど， $\bar{l}_{\mathbf{A}}$ が大なほど， $\alpha$ は大となってい る. しかしながら少なくとも $F_{\mathrm{A}}$ が 0.316 のコポリマ 一では，注㴗 $50 \%$ が孤立しており，平均鎖長も 1.5 と 短いから，加水分解の反応度がかなりに進行したところ では，末反応 AEMA 基の大部分は孤立したものになる はずである．孤立したものが加速されないるのと仮定す れば，反応末期では $k \fallingdotseq k_{0}$ となることが推察される。 それにもかかわらず, 実験結果 (Fig. 8 参照) は $(x / a)$ $=0.9$ 付近においてもな打 $k$ は反応度 $(x / a)$ とともに 增大し，加速効果が認められている.
付 記 本実験に協力された西畑裕充君に深謝する. 本報告の大要は第 20 回高分子研究発表会 (1974 年 7 月 12 日, 神戸) で発表した。

\section{文献}

1) 增原英一：高分子, 12, 644 (1973).

2) M. F. Refojo, H. Yasuda: J. Appl. Polym. Sci., 9, 2425 (1965).

3) 児玉峯一：高分子化学, 28, 746 (1971).

4) S. S. Labana: J. Polym. Sci., A-1, 8, 179 (1970).

5) J. Kopécek, D. Lim: ibid., A-1, 9, 147 (1971).

6) P. Vogt, H. G. Elias: Makromol. Chem., 157, 257 (1972).

7) Joshi R. M., S. L. Kapur: J. Sci. Ind. Res. (India) 16 B, 441 (1957).

8) M. Fineman, S. D. Ross: J. Polym. Sci., 5, 269 (1950).

9) 桜田一郎：「高重合反応」, p. 35 (1946) 高分子 化学協会.

10) T. Alfrey, C. C. Price: J. Polym. Sci., 2, 101 (1947).

11) H. Lüssi: Makromol. Chem., 103, 68 (1967).

12) J. Brardrup, E. H. Immergut: Polymer Handbook, Interscience, New York (1966) p. II-141 362.

13) 桜田一郎：工化誌, 45,1292 (1942); 高分子, 17, 21, 207 (1968)

14）坂口康義, 大森昭夫, 木村恭弘：高分子化学, 29, 25 (1972)

15）坂口康義：“高分子の反応に関する研究”，学位 論文, (1956).

16）野間头之：同志社工学会報, No. 2, 21 (1960); K. Ito, Y. Yamashita: J. Polym. Sci., A, 3, 2165 (1965). 